\title{
SHOPPERS' PERCEPTION OF RETAIL CONVENIENCE IN ONLINE SHOPPING IN BENIN CITY, NIGERIA
}

\author{
Christopher Agbonifoh*, Edith Odia \\ Department of Business Administration, Faculty of Management Sciences, University of \\ Benin, Benin City, Nigeria \\ christopher.agbonifoh@uniben.edu \\ edith.odia@uniben.edu
}

\begin{abstract}
In view of the fact that shopping is part of everyday life and that it has significant implications for everybody's livelihood and welfare, this study has investigated shoppers' perception of retail convenience in online shopping as well as examine the influence of demographic attributes on shoppers' perception of retail convenience in online shopping. A 20- item questionnaire was developed so as to measure the four different dimensions of retail convenience. It was administered on a sample of 500 respondents consisting of online shoppers in Benin City. On the whole, 423 copies of the questionnaire were returned and found usable, thus giving an $84.6 \%$ response rate. The data obtained was coded and analyzed using means, standard deviation, frequency distributions, and T-test. The results revealed that online shoppers have a favorable perception of all the dimensions measuring retail convenience. However, shoppers have a more favorable perception of search convenience. The study has also found that demographic attributes such as gender, age, education, occupation and income do not significantly influence shoppers' perception of online retail convenience. It is therefore recommended that online retailers should emphasize retail convenience, including access convenience, search convenience, transaction convenience and possession convenience as these constructs are crucial for developing retail convenience and serve as a source for competitive advantages.
\end{abstract}

Keywords: Demographic attributes, online shopping, perception, shoppers, retail convenience, Internet.

JEL classification: M31, M37.

\section{Introduction}

Before 1980, the only available option for shopping was the brick-and-mortar store ( $\mathrm{Li}, \mathrm{Lu}$ and Talebian, 2015). Although it was possible to use catalogues, with the birth of the Internet, a new method, namely online shopping, has become possible and is becoming more and more widespread. The growth of the Internet has increased the popularity of online shopping and it (online shopping) is the fourth most popular Internet activity, following e-mail, the use of instant messaging and web browsing (Ariff, et al., 2017). Nowadays, online shopping holds the attention of the retail market as millions of people shop online (Sivanesan et al., 2017).

The developments in Internet technology allow for the expansion of shopping options beyond traditional methods that may be more time consuming (Akinbode et.at., 2016). Issues with having to physically gather information with traditional shopping methods are alleviated, and shoppers are better able to efficiently use their time (Ekwueme and Akagwu, 2017).

\footnotetext{
* Corresponding author: Christopher Agbonifoh
} 
Shoppers' decision making is considerably influenced by the speed and ease with which they can access retail outlets. Several shoppers make use of the Internet in order to simplify their buying decision making (Beauchamp and Ponder, 2010). When engaging in shopping activities, shoppers spend time and effort so as to complete multiple tasks and given that today's shopper is more time-sensitive and influenced than ever, it is fit to consider the benefits of providing online shopping convenience. Online convenience is one of the main promoters of shopper's predisposition to adopt online shopping (Jiang, Yang and Jun, 2013). It is argued that the importance that shoppers placed on convenience prompts retailers to redesign store operating systems and emphasize the efficiency of the provided service (Seiders, Berry and Gresham, 2000). Online retailers are certainly able to supply more convenience as store location becomes irrelevant and shoppers may now shop from virtually any location, 24 hours a day, seven days a week (Beauchamp and Ponder, 2010). Therefore, companies must develop a more precise understanding of the impacts of online convenience.

The Internet has deeply transformed the industry practices of modern retailing and distribution management (Doherty and Ellis-Chadwick, 2006). The Internet explosion has shifted some of the traditional shopping to the online shopping environment. An increasing number and variety of firms and organizations are exploiting and creating business opportunities on and over the Internet (Jiang et al., 2013). As online shopping is a new medium, so is the consumer behavior in the field of online shopping; it is fairly diverse in nature as compared to traditional consumer behavior. With this emerging field of shopping, the interest of marketers is also the increase in studying what actually motivates shoppers to shop/buy online. Other than the factors which influence shoppers to buy online, online shoppers' demographics in terms of age, gender, income, occupation and education, as well as location of shoppers (urban and rural) and shopping experience are also important in order to define their shopping behavior (Qinghe, Wenyuan and Kaiming, 2014).

In view of the fact that shopping is part of everyday life and has significant implications for everybody's livelihood and welfare, this study investigates shoppers' perception of retail convenience in online shopping and it also examines the influence of demographic variables (gender, occupation, age, education, and income) on shoppers' perception of retail convenience in online shopping.

\section{Literature Review}

\subsection{Online Shopping}

Advances in information and communication technologies and the development of the Internet have changed business activities by allowing new ways of conducting business, and it referred to as online shopping (Zwass, 2003). Online shopping belongs to the general family of electronic commerce (Gabriel, Ogbuigwe and Ahiauzu, 2016). It involves the purchase of goods and services from a seller over the Internet. Online shopping is a process of electronically buying and selling (Laudon and Laudon, 2006) of goods and services by using with computerized business transactions through the use of Internet networks. This implies that online shopping is a process and it consists of different steps, just like in the physical method of shopping (Varma and Agarwal, 2014).

\subsection{Dimensions of Retail Convenience in Online Shopping}

The concept of convenience was proposed by Copeland (1923) in marketing literature. He classifies the consumer products into convenience goods, shopping goods, and specialty goods. Convenience is the ability to reduce shoppers' non-monetary costs, namely time, 
energy and effort, when purchasing or consuming goods and services (Berry, Seiders and Grewal, 2002; Seiders et al., 2007; Farquhar and Rowley, 2009).

To better understand the concept, researchers in this field have distinguished between different types of convenience. The two types of convenience are service convenience (Berry et al., 2002) and retail convenience (Seiders et al., 2000). Service convenience is defined (Berry et al., 2002) as consumers' time and effort perceptions related to buying or using a service. On the other hand, retail convenience is defined as shoppers' time and effort costs associated with shopping in a retail environment. Four dimensions of convenience applicable to retailers are identified in specialty literature (Seiders et al., 2000). These dimensions are: access convenience, search convenience, possession convenience and transaction convenience. They are explained below.

\section{Access Convenience}

Access convenience is defined as the "speed and ease with which shoppers can reach a retailer" (Seiders et al., 2000: 81). It encompasses the perceived time and effort necessary to initiate service delivery, that is, the actions required to request services and to receive them (Changa and Polonsky, 2012). This access may occur in person, over the phone, through a computer, or in other means as the case may be.

\section{Search Convenience}

Search convenience is the speed and ease with which shoppers identify and select goods and services they desire to buy (Seiders et al., 2000), and comprises effective communicating systems with shoppers, store design and arrangement, product demonstrations, store signage, and professional as well as knowledgeable salespeople.

\section{Transaction Convenience}

Transaction convenience is the "speed and ease with which shoppers can effect or amend transactions" (Seiders et al., 2000: 86). Traditional stores and online stores with fast checkouts and easy or liberal return policies score high in transaction convenience.

\section{Possession Convenience}

Possession convenience is the speed and ease with which shoppers can obtain the desired goods and services (Seiders et al., 2000). The main reason for choosing traditional stores over online stores is the ability to actually take immediate possession or delivery of the products (Alba et al.; Rohm and Swaminathan, 2004).

\section{The Research Hypotheses}

The research hypotheses tested in this study are as follows:

$H_{01}$ : There is no significant difference between male and female online shoppers' perception with respect to access, search, transaction and possession convenience

$H_{02}$ : There is no significant relationship between respondents' demographics (gender, age, education, occupation and income) and shoppers' perceptions of retail convenience in online shopping.

\section{Methodology}

This paper focuses on shoppers' perception of retail convenience in online shopping. The focus was aimed at online stores. The population of the study therefore consists of the totality of shoppers who are at least 18 years of age and who use online shopping mode in Benin City, Edo state. The estimated population of Benin City which is above the age of 18 is 1,627,300 (National Population Commission, 2016).

The sample size of the study was determined by using Yamane's formula, which is the application of normal approximation with $95 \%$ confidence level and 5\% error tolerance. The formula is given as: 


$$
\mathrm{n}=\frac{N}{1+N\left(e^{2}\right)}
$$

Where: $\mathrm{n}=$ sample size; $\mathrm{N}=$ population $=1,627,300 ; \mathrm{e}=$ level of significance $=0.05$

$$
\mathrm{n}=\frac{N}{1+N\left(e^{2}\right)}=\mathrm{n}=\frac{1,627,300}{1+1,627,300\left(0.05^{2}\right)}=399.901 \simeq 400
$$

Though the calculated sample size is 400 , a total of 500 questionnaires were administered in anticipation of possible invalid or improper completion by respondents.

The sampling technique adopted in this study is a combination of simple random sampling, systematic sampling and convenience sampling. First, the official Independent National Electoral Commission wards adopted during election was the initial sampling unit. In this connection the official 2018 list of wards in Benin City was used. This list of wards was obtained from INEC office in Benin City. Of the 25 wards in Benin City, ten wards were randomly selected. The second stage of the sampling process was the selection of houses using systematic sampling. The third was a convenience sampling of individual respondents from the houses selected in the second sampling stage. A questionnaire was administered in every fifth house along each street in the selected areas on the first cooperating adult encounter in each house. A situation whereby the first adult encounter refuses to cooperate or has no knowledge of online shopping; it was administered on the next willing and available adult in the same premises.

Simple random sampling procedure was applied to select 10 of 25 wards structured by the Independent National Electoral Commission in 2018. This was done to ensure that there was adequate representation of online buyers from all the wards in Benin City. Following, a form of systematic sampling technique was employed to sample every first cooperating adult respondent in every fifth house on the street in the selected area. In absence of a suitable respondent, the next house was sampled as the fifth house up until the expected 50 respondents were surveyed.

The instrument that was used for data collection in this paper is a structured questionnaire. The 20-item questionnaire was divided into two parts. The first part captured the respondents' selected demographic and socio-economic characteristics, which include: gender, occupation, age, educational qualification and income. The second part of the questionnaire contained items measuring online shopping convenience. Hypotheses were tested using T-test and Analysis of Variance (ANOVA). The Statistical Package for the Social Sciences (SPSS 20.0) was used for all the analyses. All tests were carried out at the $5 \%$ level of statistical significance.

\section{Data Analysis and Results}

\section{Shoppers' Perception of Retail Convenience in Online Shopping}

Shoppers' perception of retail convenience in online shopping was measured using the following dimensions: access, search, transaction and possession convenience. The perception index (mean score) for each of the variables presented in Table 1 was computed on a five-point scale ranging from strongly agree (5), agree (4) unsure (3), disagree (2) to strongly disagree (1). The higher the mean scores, the more positive the shoppers' perception of shopping convenience and vice versa. A score of five (5) indicates very positive perception by shoppers while a score of one (1) represents the lowest or most unfavorable perception by shoppers. The reliability values regarding access, search, transaction and possession are $0.765,0.684,0.782$ and 0.805 , respectively, by using Cronbach Alpha method.

The five (5) variables that make up access convenience were positively perceived by shoppers with a mean index of 4.20 . On the average, the most positively perceived variables are "the opening hour of the shops is convenient" (4.46), followed by "the stores are not 
crowded" (4.22), following is "it is easy to access the products you need (4.16), followed by "a wide variety of products that I need are available in these shops" (4.15) and lastly, "it is easy to locate the shops" (4.03).

Search convenience consists of four (4) variables. The average scores show that all four variables were positively perceived. The most positively perceived variable was "products are well-organized or arranged" (4.34), followed by "product sorting and classification is easy (4.31), next is "it is easy to find the products that you need (4.28) and lastly, "it is easy to get the information I need to make my purchase decision in the store" (4.15).

Transaction has four (4) variables. All variables were positively perceived by the shoppers except for "it is easy to return defective products after purchase to the store" with the lowest mean score of (2.91). The most positively perceived variables were "the checkout process is fast" (3.98), followed by "it is easy for me to conclude my purchase" (3.89) and lastly, "I do not have to make much of an effort to pay for the product" (3.86).

The next dimension was possession convenience and it has only two (2) variables. "I am satisfied with the attitude and performance of deliverymen" was more positively perceived with a mean score of (3.86) than "I get the product immediately after the payment" with a lower mean score of (2.66).

The results indicate that search convenience was perceived to be better than the other dimensions of retail convenience because the overall mean score for the different dimensions show that search convenience is perceived highest by shoppers with overall mean score of (4.27), followed by access convenience (4.20), transaction (3.66), and lastly, possession convenience (3.26).

Table 1: Shoppers' Perception of Retail Convenience in Online Shopping

\begin{tabular}{|c|c|c|}
\hline $\mathbf{S} / \mathbf{N}$ & Dimensions of Retail Convenience in Online Shopping & Mean \\
\hline & Access Convenience $(\alpha=0.765)$ & \\
\hline 1 & The opening hour of the shops is convenient. & 4.46 \\
\hline 2 & It is easy to access the products you need. & 4.16 \\
\hline 3 & A wide variety of products that I need are available in these shops. & 4.15 \\
\hline 4 & The stores are not crowded. & 4.22 \\
\hline \multirow[t]{3}{*}{5} & It is easy to locate the shops. & 4.03 \\
\hline & Overall mean for access convenience & 4.20 \\
\hline & Search Convenience $(\alpha=0.684)$ & \\
\hline 6 & Products are well-organized or arranged. & 4.34 \\
\hline 7 & It is easy to find the products that you need. & 4.28 \\
\hline 8 & Product sorting and classification is easy. & 4.31 \\
\hline \multirow[t]{3}{*}{9} & $\begin{array}{l}\text { It is easy to get the information I need to make my purchase decision in } \\
\text { the store. }\end{array}$ & 4.15 \\
\hline & Overall mean for search convenience & 4.27 \\
\hline & Transaction Convenience $(\alpha=0.782)$ & \\
\hline 10 & The checkout process is fast. & 3.98 \\
\hline 11 & It is easy to return defective products after purchase to the store. & 2.91 \\
\hline 12 & It is easy for me to conclude my purchase. & 3.89 \\
\hline \multirow[t]{3}{*}{13} & I do not have to make much of an effort to pay for the product & 3.86 \\
\hline & Overall mean for transaction convenience & 3.66 \\
\hline & Possession Convenience $(\alpha=0.805)$ & \\
\hline 14 & I get the product immediately after the payment & 2.66 \\
\hline
\end{tabular}




\begin{tabular}{|c|l|c|}
\hline S/N & Dimensions of Retail Convenience in Online Shopping & Mean \\
\hline 15 & I am satisfied with the attitude and performance of deliverymen. & 3.86 \\
\hline & Overall mean for possession convenience & $\mathbf{3 . 2 6}$ \\
\hline & Shoppers Perception of Retail Convenience & $\mathbf{3 . 8 5}$ \\
\hline
\end{tabular}

Source: Authors' fieldwork

\section{Demographic Influences on Shoppers' Perception of Retail Convenience in Online Shopping}

The demographic influences of respondents, such as gender, sex, educational qualification, occupation and income in regards to perception of retail convenience on shopping are presented in Table 2, 3, 4, 5 and 6.

Relationship between Gender and Shoppers' Perception of Retail Convenience in Online Shopping

The results presented in Table 2 show that gender $\{t=1.564 ; p=0.119\}$ does not significantly influence shoppers' perception of retail convenience at $5 \%$ level of significance. This means that the male respondents are not significantly different from their counterpart in their perception of retail convenience in online shopping.

Table 2: Relationship between Gender and Shoppers' Perception of Retail Convenience in Online Shopping

\begin{tabular}{|l|c|c|c|c|}
\hline \begin{tabular}{l|c|c|c|} 
Dimension of Retail Convenience in \\
Online Shopping
\end{tabular} & Male & Female & T & P \\
\hline Access Convenience & 4.237 & 4.159 & & \\
\cline { 1 - 4 } Search Convenience & 4.283 & 4.187 & & \\
\cline { 1 - 3 } Transaction Convenience & 3.707 & 3.551 & & \\
\hline possession Convenience & 3.240 & 3.257 & & \multirow{2}{*}{$\mathbf{1 . 5 6 4}$} \\
\hline
\end{tabular}

Source: Authors' field work

\section{Relationship between Age and Shoppers' Perception of Retail Convenience in Online Shopping}

The results show that there is no significant relationship between age and shoppers' perception of retail convenience. The F-value $(0.685)$ and $p$-value $(0.758)$ are strong evidences that age is not statistically significant at the 0.05 level of significance. This means that shoppers' perception of retail convenience in online shopping does not vary with age.

Table 3: Relationship between Age and Shoppers' Perception of Retail Convenience in Online Shopping

\begin{tabular}{|l|c|c|}
\hline Age Category & N & $\begin{array}{c}\text { Shoppers' Mean Perceptions of Retail } \\
\text { Convenience in Online Shopping }\end{array}$ \\
\hline $18-24$ & 280 & 3.836 \\
\hline $25-31$ & 69 & 3.875 \\
\hline Above 31 & 71 & 3.776 \\
\hline Overall mean & $\mathbf{4 2 0}$ & $\mathbf{3 . 8 3 3}$ \\
\hline F-statistics & $\mathbf{0 . 6 8 5}$ \\
\hline p-value & $\mathbf{0 . 7 5 8}$ \\
\hline
\end{tabular}

Source: Authors' field work 
Relationship between Education and Shoppers' Perception of Retail Convenience in Online Shopping

The results presented in Table 4 show the mean scores for the various education categories of shoppers. The results depict that there is no significant relationship between education and shoppers' perception of retail convenience. The F-value (1.801) and p-value $(0.128)$ are strong indications that education does not influence shoppers' perception at the 0.05 level of significance. This means that the perception of online shopping of the more educated shoppers is not significantly different from that of their counterparts.

Table 4: Relationship between Education and Shoppers' Perception of Retail Convenience in Online Shopping

\begin{tabular}{|l|c|c|}
\hline Education & $\mathbf{N}$ & $\begin{array}{c}\text { Shoppers' Mean Perceptions of Retail } \\
\text { Convenience in Online Shopping }\end{array}$ \\
\hline Primary & 5 & 4.003 \\
\hline SSCE/WAEC or equivalent & 120 & 3.864 \\
\hline OND/NCE or equivalent & 18 & 3.857 \\
\hline B.Sc., B.A., HND or equivalent & 205 & 3.861 \\
\hline Postgraduate Degree & 63 & 3.686 \\
\hline Overall mean & $\mathbf{4 1 1}$ & $\mathbf{3 . 8 3 6}$ \\
\hline F-statistics & & $\mathbf{1 . 8 0 1}$ \\
\hline p-value & $\mathbf{0 . 1 2 8}$ \\
\hline
\end{tabular}

Source: Authors' field work.

Relationship between Occupation and Shoppers' Perception of Retail Convenience in Online Shopping

The results in Table 6 reveal that there is no significant relationship between occupation and shoppers' perception of retail convenience. The F-value $(0.441)$ and p-value $(0.779)$ are indications that occupation is not statistically significant at the 0.05 level of significance. This suggests that respondents' occupation does not affect their perception of online shopping.

Table 5: Relationship between Occupation and Shoppers' Perception of Retail Convenience in Online Shopping

\begin{tabular}{|l|c|c|}
\hline Occupation & $\mathbf{N}$ & $\begin{array}{c}\text { Shoppers' Mean Perceptions of Retail } \\
\text { Convenience in Online Shopping }\end{array}$ \\
\hline Students & 299 & 3.849 \\
\hline Self employed & 36 & 3.759 \\
\hline Civil/public servant & 46 & 3.773 \\
\hline Others & 28 & 3.859 \\
\hline Overall mean & $\mathbf{4 0 9}$ & $\mathbf{3 . 8 3 3}$ \\
\hline F-statistics & & $\mathbf{0 . 4 4 1}$ \\
\hline p-value & $\mathbf{0 . 7 7 9}$ \\
\hline
\end{tabular}

Source: Authors' field work.

Relationship between Income and Shoppers' Perception of Retail Convenience in Online Shopping

The results in Table 6 reveal that there is no significant relationship between income and shoppers' perception of retail convenience. The F-value (1.563) and p-value (0.145) are strong evidences that income is not statistically significant at the 0.05 level of significance. 
We can therefore conclude that respondents' income does not affect their perception of online shopping.

Table 6: Relationship between Income and Shoppers' Perception of Retail Convenience in Online Shopping

\begin{tabular}{|c|c|c|}
\hline Income Level & $\mathbf{N}$ & $\begin{array}{l}\text { Shoppers' Mean Perceptions of Retail } \\
\text { Convenience in Online Shopping }\end{array}$ \\
\hline Below $\mathrm{N50,} 000$ & 244 & 3.816 \\
\hline$\# 50,001-\$ 100,000$ & 53 & 3.908 \\
\hline$\# 100,001-\# 150,000$ & 33 & 3.599 \\
\hline Above 150,000 & 31 & 3.979 \\
\hline Overall mean & 361 & 3.823 \\
\hline \multicolumn{2}{|l|}{ F-statistics } & 1.563 \\
\hline \multicolumn{2}{|l|}{ p-value } & 0.145 \\
\hline
\end{tabular}

Source: Author's field work

\section{Discussion of Findings}

The objective of this study was to examine shoppers' perception of retail convenience in online shopping. The result shows that the four dimensions of retail convenience were positively perceived by shoppers. This result confirms an earlier finding by Beauchamp and Ponder (2010) that online shopping is positively perceived by shoppers in the United State of America. They reported mean scores of $6.43,6.11,6.26$ and 6.13 for access, search, transaction and possession convenience, respectively. Similarly, Jiang, Yang and Jun (2013) found that online shoppers have a favorable perception of online shopping in Hong Kong. This finding is also supported by the study conducted in South Africa by Mpinganjira (2015) who found that online shoppers have a favorable perception of search and possession convenience.

This study found that demographic variables (gender, age, education, occupation and income) do not have a significant relationship with shoppers' perception of retail convenience in online shopping. The implication of this finding is that the demographic variables do not play a significant role in explaining shoppers' perceptions concerning online shopping.

More specifically, gender had no significant relationship with perceptions concerning retail convenience in online shopping among shoppers in Benin City. Male and female shoppers perceive retail convenience in online shopping in the same way. The possible reason for this finding is because both male and females go through similar process of accessing, searching and purchasing goods. This study contradicts the findings of Slyke, Comunale and Belanger (2002), Rodgers and Harris (2003), Stafford, Stafford and Schkade (2004), Punj (2011); Richa (2012) and Lubis (2018); according to them, gender had a significant impact on shoppers' perceptions of retail convenience in online shopping.

This study found that age had no significant relationship with shoppers' perceptions of retail convenience in online shopping. In contrast, Lubis (2018) found that age had a significant relationship on shoppers' perceptions of retail convenience in online shopping. The finding from this study also contradicts previous findings by Punj (2011) and Richa (2012) that shoppers' demographic variables affect their shopping preferences.

More than three quarter of the shoppers surveyed in this study belong to the youthful age of between 18-31 years old. The youths appear to be more ardent in the use of ICT knowledge, which is very important in the adoption of online shopping. Given this background of the present study, it would not be surprising if education is less relevant in the perception. 
This study has found that education had no significant relationship with shoppers' perceptions of retail convenience in online shopping. Possible explanation for the nonrelevance of education in explaining shoppers' perception could be because of the increasing attention given to ICT education in both the Nigerian secondary and tertiary institutions. By contrast, Kwarteng and Pilik (2016) found that education had a significant relationship with shoppers' perceptions of retail convenience. Research findings have shown that online shoppers largely consist of people with higher level of education (Kehoe, Pitkow and Rogers, 1998; Hoffman, Kalsbeek and Novak, 1996). Similarly, Lubis (2018) found that education had a significant relationship with shoppers' perceptions of retail convenience in online shopping. Furthermore, the findings from this study also contradict previous findings by Punj (2011) and Richa (2012) that shoppers' demographic variables affect their shopping preferences.

Lastly, on the influence of demographic variables, this study found that income had no significant relationship with shoppers' perceptions of retail convenience in online shopping. This is not consistent with earlier reports by Hoffman et al. (1996) and Kehoe et al. (1998) that income had a significant relationship with shoppers' perceptions of retail convenience in online shopping.

\section{Conclusion}

Shoppers are more time constarined than ever before and the development of retail perceived convenience in online business is therefore an important marketing strategy. The study has attempted to investigate shoppers' perceptions of retail convenience in online shopping in Benin City. The results indicate that search convenience was perceived to be better than the other dimensions of retail convenience because the overall mean score for the different dimensions shows that search convenience is perceived highest by shoppers. However, there is still room for improvement in adding value to the retail experience of shoppers on the four (4) dimensions of retail convenience. The outcome of the demographic influences indicates that there is no significant relationship with shoppers' perceptions of retail convenience in online shopping. Since demographic variables do not explain variation in shoppers' perception of retail convenience in online shopping, there may be no need for segmentation of the market for online business. Future researchers may conduct further investigation into the influences of other variable such as psychological and psychographic variables.

\section{Recommendations}

It is recommended that online retailers should emphasize retail convenience, including access, search, transaction and possession convenience, as these constructs are crucial for developing retail convenience and serve as a source for competitive advantages. We also recommend that online retailers/vendors should improve on their delivery strategies to ensure prompt delivery of products to shoppers in order to better satisfy their needs.

\section{References}

Akinbode, S. O., Ekpudu, J. E., Ojo, O. T., and Are, A. O. 2016. Consumer Acceptability and Patronage of Internet Retail Market in Nigeria. Journal of Business and Management, 18, pp. 81-89

Alba, J., Lynch, J., Weitz, B., Janiszewski, C., Lutz, R., Sawyer, A., and Wood, S. 1997. Interactive Home Shopping: Consumer, Retailer, and Manufacturer Incentives to Participate In Electronic Marketplaces. The Journal of Marketing, 2, pp. 38-53. 
Ariff, M. S. M., Sylvester, M., Zakuan, N., Ismail, K., and Ali, K. M. 2017. Consumer Perceived Risk, Attitude and Online Shopping Behaviour; Empirical Evidence from Malaysia. In IOP Conference Series: Materials Science and Engineering (58, 1, 012007). IOP Publishing.

Beauchamp, M. B., and Ponder, N. 2010. Perceptions of Retail Convenience for in-store and Online Shoppers: The Marketing Management Journal, 20, pp. 49-65.

Berry, L. L. Seiders, K. and Grewal, D. 2002. Understanding Service Convenience. Journal of Marketing, 66, pp.1-17.

Changa, Y. W. and Polonsky, M. J. 2012. The Influence of Multiple Types of Service Convenience on Behavioural Intentions: The Mediating Role Of Consumer Satisfaction in a Taiwanese Leisure Setting. International Journal of Hospitality Management, 31, pp. 107118.

Copeland, H.L., 1923. Building method and means. U.S. Patent, 1, pp. 444,588.

Doherty, N. F., and Ellis-Chadwick, F. E. 2006. New Perspectives in Internet Retailing: A Review and Strategic Critique of the Field. International Journal of Retail and Distribution Management, 34, pp. 411-428.

Ekwueme, E. and Akagwu, A. N. 2017. The Influence of Online Marketing of Jumia and Konga on Consumer Purchasing Behaviour among Kogi State Residents of Nigeria. Global Journal of Human-Social Science: An Arts \& Humanities - Psychology, 17, pp. 25-32

Farquhar, J. D. and Rowley, J. 2009. Convenience: A Service Perspective. Marketing Theory, 9, pp. 425-38.

Gabriel, J. M. O., Ogbuigwe, T. D., and Ahiauzu, L. U. 2016. Online Shopping Systems in Nigeria: Evolution, Trend and Prospects. Asian Research Journal of Arts and Social Sciences 1, pp. 1-7.

Hoffman, D. L., Kalsbeek, W. D., and Novak, T. P. 1996. Internet and Web Use in the US. Communications of the ACM, 39, pp. 36-46.

Jiang, L. Yang, Z., and Jun, M. 2013. Measuring Consumer Perceptions of Online Shopping Convenience. Journal of Service Management, 24, pp. 191-214

Kehoe, C., Pitkow, J., and Rogers, J. (1998). GVU's ninth WWW user survey report. Atlanta, GA: Office of Technology Licensing, Georgia Tech Research Corporation.

Kwarteng, M. A. and Pilik, M. 2016. Shopping in a Developing Country: A Demographic Perspective. International Journal of Entrepreneurial Knowledge, 1, pp. 90-102.

Laudon, K. and Laudon, J. 2006. Management Information Systems, Managing the Digital Firm. $7^{\text {th }}$ Edition, New Delhi: Pearson Prentice Hall.

Li, E. Lu, S. and Talebian, L. 2015. Online Versus Bricks-and-Mortar Retailing: A Comparison of Price, Assortment, and Delivery Time. International Journal of Production Research, 3, pp. 1-25

Lubis, A. N. 2018. Evaluating the Customer Preferences of Online Shopping: Demographic Factors and Online Shop Application Issue. Academy of Strategic Management Journal, 17, pp. 1939-6104

Mpinganjira, M. 2015. Online Store Service Convenience, Customer Satisfaction and Behavioural Intentions: A Focus on Utilitarian Oriented Shoppers, Journal of Economics and Behavioral Studies, 7, pp. 36-49,

Punj, G. (2011). Effect of Consumer Beliefs on Online Purchase Behavior: The Influence of Demographic Characteristics and Consumption Values. Journal of Interactive Marketing, 25, pp. 134-144.

Qinghe, Y., Wenyuan, C., and Kaiming, L. 2014. The Online Shopping Change the Retail Business Model: A Survey of the People Using Online Shopping in China. Journal of Business and Management, 15, pp. 77-110. 
Richa, D. 2012. Impact of Demographic Factors of Consumers on Online Shopping Behavior: A study of Consumers in India. International Journal of Engineering and Management Sciences, 3, pp. 43-52.

Rodgers, S. and Harris, M. A. 2003. Gender and E-commerce: An Exploratory Study. Journal of Advertising Research, 43, pp. 322-329.

Rohm, A. J., and Swaminathan, V. 2004. A Typology of Online Shoppers Based on Shopping Motivations. Journal of Business Research, 57, pp. 748-757.

Seiders, K., Berry, L. L., and Gresham, L. G. 2000. Attention, Retailers! How Convenient is your Convenience Strategy? Sloan Management Review, 41, pp. 79-85

Seiders, K., Voss, G. B., Godfrey, A. L. and Grewal, D. 2007. SERVCON: Development and Validation of a Multidimensional Service Convenience Scale. Journal of the Academy Marketing Science, 35, pp. 144-156.

Sivanesan, R., Monisha, C., Babisha, V. and Abisha, S. A. 2017. Comparative Study on Factors Influencing Online and Traditional Shopping. International Journal of Research in Management \& Business Studies, 4, pp. 26-34

Slyke, C.V., Comunale, C. L. and Belanger, F. 2002. Gender Differences in Perceptions of Web-Based Shopping. Communications of the ACM, 45, pp. 82-86.

Stafford, T. F., Stafford, M. R. and Schkade, L. L. 2004. Determining Uses and Gratification for the Internet. Decision Sciences, 35, pp. 259-285.

Varma, I. G., and Agarwal, M. R. 2014. Online Buying Behaviour of Home makers in Western Suburbs of Mumbai and Social Media Influence. Journal of Business and Management, 16, pp. 42-65.

Zwass, V. (2003). Electronic Commerce and Organizational Innovation: Aspects and Opportunities. International Journal of Electronic Commerce, 7, pp. 7-37.

\section{Bio-note}

Dr. Agbonifoh, C. I. is a Lecturer II in the Department of Business Administration at the University of Benin, Benin City, Nigeria. His research area includes consumer behaviour, brand loyalty and internet marketing.

Dr. Odia, E. O. is a Senior Lecturer in the Department of Business Administration at the University of Benin, Benin City, Nigeria. Her research area includes branding, green marketing, consumer behaviour, and gender issues. Before joining University of Benin in 2011, she acted as the HOD, Department of Accounting/Business Administration, Benson Idahosa University. She is an Associate Examiner for the National Open University of Nigeria (NOU) as well as an Assessor for Institute of Chartered Accountant of Nigeria (ICAN). She is a Member of The Academy of Management Nigeria and Organisation of Women in Science for Developing Countries (OWSD). 